\title{
EFFECTS OF PHOTOTHERMAL MANIPULATIONS ON THE ARTIFICIAL REPRODUCTION OF BARBEL, BARBUS BARBUS (ACTINOPTERYGII: CYPRINIFORMES: CYPRINIDAE): A PILOT STUDY
}

\author{
Rafał KAMIŃSKI*, Michał KORWIN-KOSSAKOWSKI, and Jacek WOLNICKI \\ The Stanistaw Sakowicz Inland Fisheries Institute in Olsztyn, Pond Fishery Department, Żabieniec, \\ 05-500 Piaseczno, Poland
}

Kamiński R., Korwin-Kossakowski M., Wolnicki J. 2012. Effects of photothermal manipulations on the artificial reproduction of barbel, Barbus barbus (Actinopterygii: Cypriniformes: Cyprinidae): a pilot study. Acta Ichthyol. Piscat. 42 (4): 329-333.

\begin{abstract}
The effects of photothermal manipulations on the artificial reproduction of female Barbus barbus (L.) (age 6+, 0.3-0.8 kg body weight) were studied under controlled conditions. The experiment was preceded by a 3-month period of wintering (Light/Dark hourly regime 9L : 15D-13L : 11D; temperature $8-12^{\circ} \mathrm{C}$ ). The experiment commenced when the photoperiod was changed promptly from $11 \mathrm{~L}: 13 \mathrm{D}$ to $14 \mathrm{~L}: 10 \mathrm{D}$. As the experiment progressed, the photoperiod gradually changed to $16 \mathrm{~L}: 8 \mathrm{D}$. After 50 days of photostimulation, water temperature was increased from 12 to $17^{\circ} \mathrm{C}$ within $24 \mathrm{~h}$, and stabilized for the next 14 or 22 days. When photothermal stimulation was completed ( 65 or 73 days, respectively), fish were treated with mGnRH-based ovulating agent Ovopel. The ovulation rate amounted to $33 \%$ and $22 \%$, respectively for the shorter and longer stimulation time (difference insignificant at $P \leq 0.05$ ). Longer photothermal stimulation resulted in lower variability of latency time, higher relative weight of stripped eggs, and higher relative working fecundity. The undesirable effect was the triggering of oocyte resorption in $11 \%$ of females.
\end{abstract}

Keywords: artificial reproduction, barbel, Barbus barbus, photoperiod, temperature, stimulation

The barbel, Barbus barbus (L.), is a large rheophilous cyprinid fish, indigenous to many European rivers, and important for sport fishing. Many barbel populations are declining due to anthropogenic destruction or alterations in the critical habitat (Philippart et al. 1989, Schiemer and Spindler 1989). In order to compensate for its diminished natural recruitment, artificial propagation of barbel has been conducted (Kouřil et al. 1988, Philippart et al. 1989, Poncin and Philippart 2002, Targońska et al. 2011). The indoor method of reproduction of barbel was developed in the 1980's and 1990's (Philippart et al. 1989, Poncin 1989, 1992). Pursuant to this method, spawner maturation was stimulated with daily lighting period manipulations at a constant water temperature of $20^{\circ} \mathrm{C}$. Under a daily lighting period longer than $9 \mathrm{~h}$, ovulation occurred over a period of six months with up to 15 batches of eggs per female at intervals of 10-20 days (Poncin and Philippart 2002). This method potentially provides an opportunity to produce a large quantity of eggs using a relatively low number of females. However, the quality of eggs obtained using a similar method in numerous batches proved to be low (Policar et al. 2010). Moreover, obtaining eggs in multiple small batches causes serious complications in large- scale offspring production. Thus, the applicability of this technique appears to be limited. On the other hand, results of artificial reproduction of B. barbus with hormonal stimulation are scarce and often unsatisfying, probably due to poor synchronisation of gonadal maturation in females, typical of multiple-spawner cyprinid fish. Therefore, it is highly desirable to develop a method ensuring effective control of this process, preferably by appropriate manipulations of exclusively environmental factors.

The objective of this study was to test the hypothesis that a low difference in the duration of photothermal stimulation of $B$. barbus females can significantly influence the results of their artificial reproduction.

The experiment was carried out on 6-year-old B. barbus females $(n=36)$ reared from hatching under controlled conditions. They reached sexual maturity at the age of $2+$ or $3+$. During the experimental year, similarly to the preceding years, the spawners were kept at a seasonally changing natural photoperiod and a water temperature from $8-12^{\circ} \mathrm{C}$ during the winter to $18-23^{\circ} \mathrm{C}$ during the summer (Fig. 1). The fish were fed a commercial diet for spawners Aller Rep (Aller Aqua, Denmark, 53\% crude protein and $14 \%$ crude fat) every other day. Once a week,

\footnotetext{
* Correspondence: Dr Rafał Kamiński Instytut Rybactwa Śródlądowego im. Stanisława Sakowicza, Zakład Rybactwa Stawowego, Żabieniec, 05-500 Piaseczno, Poland, phone: +4822756 20 44/88, e-mail: erka@infish.com.pl.
} 
they were fed commercially available frozen maggots ("greenbottle fly" larvae). The daily feeding rate amounted to $1 \%$ of fish biomass for dry diet and $2 \%$ for maggots (fresh weight).

The experiment commenced on the last day of February and ended on 6 May in group A and on 14 May in group B. The female spawners were anaesthetised in 2-phenoxyethanol water solution $\left(0.45 \mathrm{~g} \cdot \mathrm{L}^{-1}\right)$. This was the standard procedure before handling and examining the fish during the experiment. The sedated fish were measured (total length, TL; mm), weighed (body weight, BW; g), and randomly assigned to groups A and $\mathrm{B}(n=18$ for each, Table 1). Each fish group was held in a separate tank ( $V=1000 \mathrm{~L}$ ). The photoperiod (Light/Dark hourly regime) was changed promptly from $11 \mathrm{~L}: 13 \mathrm{D}$ to $14 \mathrm{~L}: 10 \mathrm{D}$ by increasing the daily period of illumination with fluorescent tubes (daylight type, about $450 \mathrm{~lx}$ at the water surface). The fish tanks were not completely isolated from natural light with a maximum intensity of $50 \mathrm{~lx}$. Therefore, the photoperiod changed to $16 \mathrm{~L}: 8 \mathrm{D}$ along with the increasing natural daylight period as the experiment progressed (Fig. 1). Group A was subject to stimulation with photoperiod for 65 days, while group B for 73 days. Thermal stimulation was employed in the last 15 or
23 days of the photostimulation period in group A and B, respectively. Temperature was increased from 12 to $17^{\circ} \mathrm{C}$ within $24 \mathrm{~h}$, and then stabilized (Fig. 1).

During the experiment, the fish were fed the Aller Rep diet every other day with a daily rate of $0.25 \%$ of fish biomass. Once a week, the fish were additionally fed defrosted maggots corresponding to $7.5 \%$ of fish biomass daily. Hormonal stimulation was performed on the day following the completion of photothermal (PT) stimulation. Feeding ceased $24 \mathrm{~h}$ before the initiation of hormonal stimulation. All of the fish were measured, weighed, and stimulated with intraperitoneally injected ovulation inducing agent Ovopel, obtainable as pellets containing 18-20 $\mathrm{mg}$ of mammalian GnRHa [(D-Ala ${ }^{6}$, Pro $\left.\left.{ }^{9} \mathrm{NEt}\right)-\mathrm{mGnRH}\right]$ and $8-10 \mathrm{mg}$ of metoclopramide as dopamine antagonist (Interfish, Hungary). It was applied following homogenisation with $0.7 \% \mathrm{NaCl}$ water solution at two doses of 0.2 pellet $\cdot \mathrm{kg}^{-1}$ and 1.0 pellet $\cdot \mathrm{kg}^{-1}$, injected at $12 \mathrm{~h}$ interval (Horváth et al. 1997). Semen used in the experiment was collected from 30 males not subject to hormonal treatment.

After being injected with Ovopel, the fish remained under the same photoperiod and temperature regime as before. They were checked for ovulation $24,36,48$, and

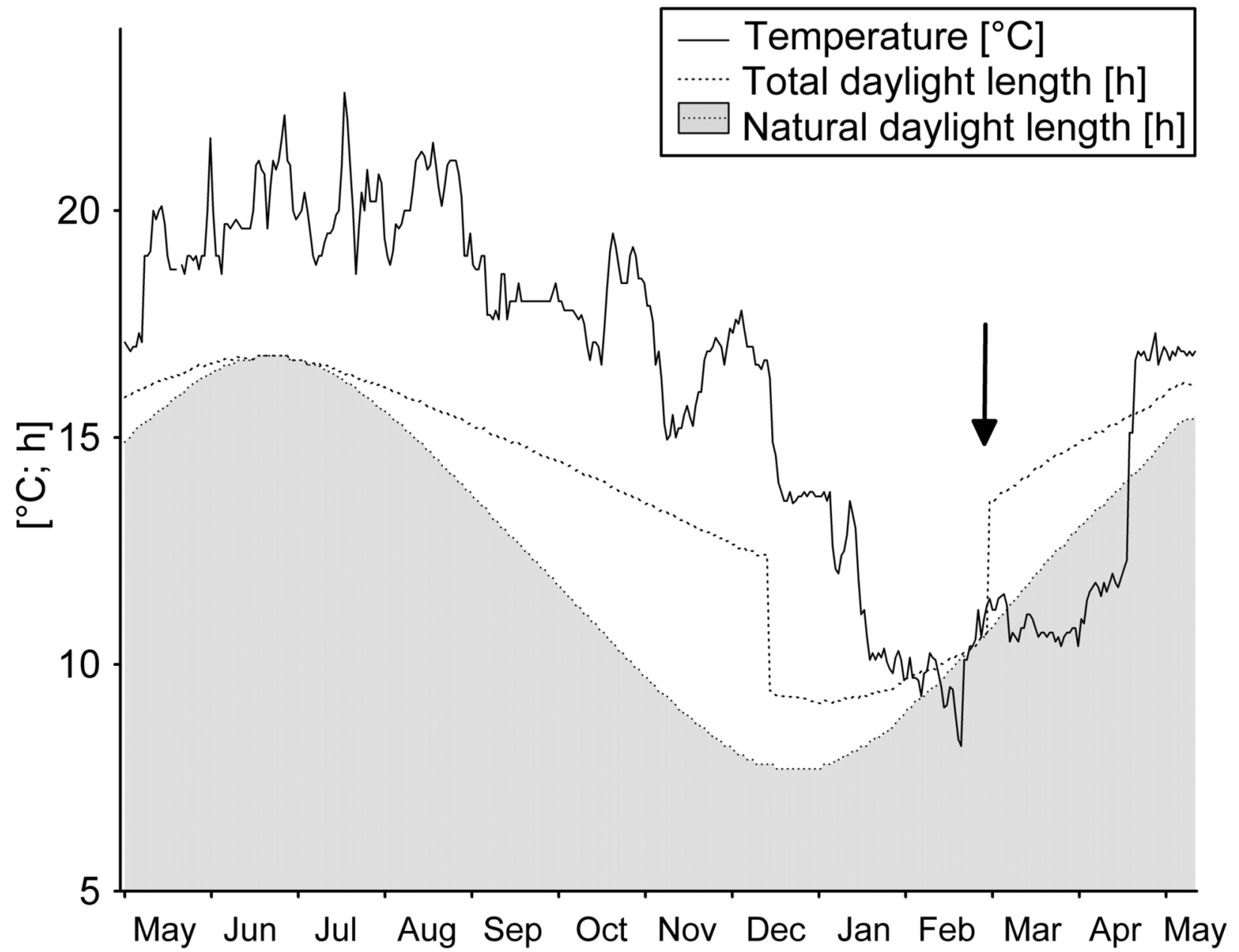

Fig. 1. Daylight length and water temperature changes a year before and during the experiment; The arrow indicates the beginning of the experiment 
56 hours after the last injection. Only fish releasing more than $1 \mathrm{~g}$ of eggs were considered as ovulated. Females releasing partially resorbed oocytes in opaque ovarian liquid were considered overripe. For each ovulating female, the relative weight of stripped eggs was determined.

A weighed sample of 179-353 eggs was taken from the first batch of eggs obtained from each female for fertilization (dry method) and incubation separately. Sperm was taken from 5 randomly selected males. The eggs were incubated at a temperature of $17.4-18.0^{\circ} \mathrm{C}$ in flow-through aquaria $\left(\mathrm{V}=5 \mathrm{~L}\right.$, constant water flow $\left.0.2 \mathrm{~L} \cdot \mathrm{min}^{-1}\right)$ illuminated by fluorescent tubes from $8.00 \mathrm{~h}$ to $21.00 \mathrm{~h}$ with an intensity of about $1000 \mathrm{~lx}$ at the water surface.

After $24 \mathrm{~h}$ of incubation, the eggs were counted. Based on this data, mean weight of a fresh egg and working fecundity were calculated. At the same time, 21-30 eggs from each sample were taken in a small amount of water to take photographs. The eggs were photographed with a Nikon SMZ1500 stereomicroscope and an Olympus E-5060 WZ digital camera. All photographs were calibrated. Based on the photographs, the diameter of all eggs in the samples was measured with image analysis software (PPom-an original program by L. Myszkowski) to the nearest $0.01 \mathrm{~mm}$, and mean diameter of water-hardened (swollen) eggs was determined. After 5-7 min, they were returned to the respective incubation aquaria. During incubation, all dead eggs were counted and removed twice a day. After 6 days $\left(105-106 \mathrm{D}^{\circ}\right)$ of incubation, mass hatching occurred in all aquaria. Two days later, all hatched larvae were counted, and the hatching rate was determined.

Water temperature and dissolved oxygen content were measured twice a day. Nitrate concentration, ammonia concentration, and $\mathrm{pH}$ were determined every two days. Water saturation with oxygen ranged from $60 \%$ to $86 \%$ in the tanks with spawners, and from $96 \%$ to $99 \%$ in the incubating aquaria. Nitrite concentration was below $0.02 \mathrm{mg} \cdot \mathrm{L}^{-1}$. Ammonia content was lower than $0.2 \mathrm{mg} \cdot \mathrm{L}^{-1}$, and $\mathrm{pH}$ varied from 7.8 to 8.0 . The fish condition coefficient $(K)$ was calculated using the formula:

$$
K=10^{5} \cdot \mathrm{BW} \cdot \mathrm{TL}^{-3}
$$

where BW is body weight [g], and TL is total length [mm].

In both groups, ovulation started $24 \mathrm{~h}$ after the last injection, but only in group B all females released eggs at the same time. The ovulation rate amounted to $33 \%(n=6)$ in group A and $22 \%$ in group B $(n=4$; difference insignificant; Table 2). Similar ovulation rates for hormonally induced female $B$. barbus were reported by other authors (Kouřil et al. 1988, Kamiński and Wolnicki unpublished data).

In contrast to the ovulation rate, the 8-day prolongation of photothermal stimulation of females positively influenced the unification of latency time, the relative weight of stripped eggs, and the relative working fecundity (Table 2). These results suggest better gonadal maturity in ovulated females after 73-day photoperiodic stimulation

Total length, body weight, and condition coefficient of Barbus barbus females in experimental groups treated with Ovopel ovulating agent after different photothermal stimulations

\begin{tabular}{lcc}
\hline Group & A & B \\
\hline Total length [cm] & $40.3 \pm 2.5$ & $39.8 \pm 2.9$ \\
Body weight [g] & $536 \pm 101$ & $516 \pm 108$ \\
Condition coefficient & $0.81 \pm 0.03$ & $0.81 \pm 0.03$ \\
Duration of photoperiodic stimulation [days] & 65 & 73 \\
Duration of thermal stimulation [days] & 15 & 23 \\
\hline
\end{tabular}

Ovopel was used in two doses of 0.5 and 1.0 pellet $\cdot \mathrm{kg}^{-1}$ administered in a $12 \mathrm{~h}$ interval. Data for total length, body weight, and condition coefficient are means $\pm \mathrm{SD}(n=18)$.

Results of reproduction Barbus barbus females treated with Ovopel

Table 2 after different photothermal stimulations

\begin{tabular}{lcc}
\hline Group & $\mathrm{A}$ & $\mathrm{B}$ \\
\hline Ovulation latency [h] & $24-48$ & 24 \\
Ovulation rate [\%] & $33^{\mathrm{a}}$ & $22^{\mathrm{a}}$ \\
Females with overripe eggs [\%] & $0.0^{\mathrm{b}}$ & $11.1^{\mathrm{a}}$ \\
Relative weight of stripped eggs [\% of BW] & $4.39 \pm 1.10^{\mathrm{b}}$ & $7.25 \pm 1.11^{\mathrm{a}}$ \\
Working fecundity [eggs] & $2328 \pm 344^{\mathrm{a}}$ & $2874 \pm 532^{\mathrm{a}}$ \\
Relative working fecundity [eggs kg-1] & $4663 \pm 835^{\mathrm{b}}$ & $6195 \pm 1042^{\mathrm{a}}$ \\
\hline
\end{tabular}

Percentages of ovulation rate and overripe females $(n=18)$ were normalised using angular transformation (Sokal and Rohlf 1969). Data for relative weight of stripped eggs, working fecundity and relative working fecundity are means $\pm \operatorname{SD}(n=6$ for group A and 4 for group B). The respective mean values were compared using Student's $t$-test. Within rows values not sharing a superscript letter are significantly different $(P \leq 0.05)$. 
combined with 23-day thermal stimulation. The negative effect was presence of overripe females (Table 2). No differences between groups were found for mean values of fresh egg wet weight, water-hardened egg diameter and larvae hatching rate between both experimental groups (Table 3).

Photoperiod and temperature are major environmental factors affecting the annual reproductive cycle in cyprinid fish species. These factors refer to cyprinid fish species occurring naturally in moderate climate zones (Bieniarz and Epler 1991). In B. barbus, photoperiod and temperature were employed for stimulating spontaneous ovulation under controlled conditions (Philippart et al. 1989, Poncin 1989, 1992, Baras and Philippart 1999, Poncin and Philippart 2002). Results of Poncin (1989) suggest that the minimum natural daylight length required for successful spawning of B. barbus females is about $9 \mathrm{~h}$. In Belgium $\left(51^{\circ} \mathrm{N}\right)$, such daylight length is reached in January. However, in the Ourthe River in Belgium the first seasonal spawning starts in April or May, when the daylight length is $14-16 \mathrm{~h}$ and minimum daily water temperature exceeds $13.5^{\circ} \mathrm{C}$ (Baras and Philippart 1999). Likewise, Hancock et al. (1976) found spawning B. barbus individuals in England in May and June at $13.5^{\circ} \mathrm{C}$. Thus, under natural conditions the photoperiod limit for natural reproduction is exceeded relatively long before the initiation of the first seasonal spawning.

The aforementioned data suggest that not photoperiod, but temperature plays a major role in the initiation of the $B$. barbus natural spawning season. In our experiment, thermal stimulation lasting 15-23 days with an increase in water temperature to the level favourable for B. barbus reproduction $\left(17^{\circ} \mathrm{C}\right)$ was applied at the end of a much longer period of photostimulation (65-73 days). During the entire stimulation period, daylight was longer than the minimum of $9 \mathrm{~h}$ required for spontaneous ovulation in captivity (Poncin 1989). Therefore, it appears that increased water temperature was a factor triggering final oocyte maturation and that photoperiod was not the factor preventing ovulation.

In our experiment environmental factors were applied to stimulate gonadal maturation, but ovulation was induced with hormonal treatment. Stimulation of ovulation with hormonal treatment is effective so currently widely applied in cyprinid fish aquaculture (Podhorec and Kouril 2009). GnRH analogues combined with dopamine antagonists, including Ovopel, proved to be effective also in the case of B. barbus (see Targońska et al. 2011). However, hormonal stimulation can effectively induce ovulation only in ripe females. Thus, the unsatisfactory low ovulation rates $(33 \%-22 \%)$ in the presently reported study apparently resulted from poor synchronisation of female readiness for spawning, despite identical photoperiodic, thermal, and hormonal stimulation of all individuals within the experimental groups. The 8-day longer period of photothermal stimulation in female $B$. barbus resulted in perfect unification of latency time, higher relative weight of stripped eggs, and higher relative working
Table 3

Characteristics of eggs obtained

from Barbus barbus females treated

with Ovopel ovulating agent

after different photothermal stimulations

\begin{tabular}{lll}
\hline Group & \multicolumn{1}{c}{ A } & \multicolumn{1}{c}{ B } \\
\hline Fresh egg wet weight $[\mathrm{mg}]$ & $10.3 \pm 1.7$ & $11.8 \pm 1.9$ \\
Water-hardened egg diameter $[\mathrm{mm}]$ & $2.94 \pm 0.15$ & $3.03 \pm 0.04$ \\
Larvae hatching rate [\%] & $86.9 \pm 11.7$ & $96.4 \pm 2.3$ \\
\hline
\end{tabular}

Data for egg weight, water-hardened egg diameter and hatching rate are means $\pm \mathrm{SD}(n=6$; for group A and 4 for group B). Differences between the respective mean values are insignificant (Student's $t$-test; $P \leq 0.05$ ).

fecundity as compared to those stimulated shorter. However, it was at the expense of the appearance of fish with overripe eggs, which also indicates asynchronous gonadal maturation, remaining the key and unsolved problem in this difficult to reproduce cyprinid species.

\section{ACKNOWLEDGEMENTS}

The study was financially supported by the S-001 Project of the Inland Fisheries Institute in Olsztyn, Poland.

\section{REFERENCES}

Baras E., Philippart J.C. 1999. Adaptive and evolutionary significance of a reproductive thermal threshold in Barbus barbus. Journal of Fish Biology 55 (2): 354-375.

DOI: $10.1111 / j .1095-8649.1999 . t b 00684 . x$

Bieniarz K., Epler P. 1991. Rozród ryb. [Fish reproduction.] Lettra, Kraków. [In Polish].

Hancock R.S., Jones J.W., Shaw R. 1976. A preliminary report on the spawning behaviour and nature of sexual selection in the barbel, Barbus barbus (L.). Journal of Fish Biology 9 (1): 21-28.

DOI: $10.1111 / j .1095-8649.1976 . t b 04658 . x$

Horváth L., Szabó T., Burke J. 1997. Hatchery testing of GnRH analogue-containing pellets on ovulation in four cyprinid species. Polish Archives of Hydrobiology 44 (1-2): 221-226.

Kouřil J., Filla V., Sandera K., Barth T., Flegel M. 1988. Hormonally induced stripping of the female barbel (Barbus barbus L.) using carp pituitary and LH-RH analogue. Bulletin VURH Vodnany 3: 18-25.

Philippart J.C., Mélard C., Poncin P. 1989. Intensive culture of the common barbel, Barbus barbus (L.) for restocking. Pp. 483-491. In: De Pauw N., Jaspers E., Ackefors H., Wilkins N. (eds.) Aquaculture - a biotechnology in progress. European Aquaculture Society, Bredene, Belgium.

Podhorec P., Kouril J. 2009. Induction of final oocyte maturation in Cyprinidae fish by hypothalamic factors: a review. Veterinarni Medicina 54 (3): 97-110.

Policar T., Podhorec P., Stejskal V., Hamackova J., Alavi S.M.H. 2010. Fertilization and hatching rates and larval performance in captive common barbel (Barbus barbus L.) throughout the spawning season. Journal of Applied Ichthyology 
26 (5): 812-815.

DOI: $10.1111 / \mathrm{j} .1439-0426.2010 .01564 . x$

Poncin P. 1989. Effects of different photoperiods on the reproduction of the barbel, Barbus barbus (L.), reared at constant temperature. Journal of Fish Biology 35 (3): 395-400.

DOI: $10.1111 / j .1095-8649.1989 . t b 02991 . x$

Poncin P. 1992. Influence of the daily distribution of light on reproduction in the barbel, Barbus barbus (L.). Journal of Fish Biology 41 (6): 993-997.

DOI: $10.1111 /$ j.1095-8649.1992.tb02726.x

Poncin P., Philippart J.C. 2002. The role of aquaculture in fish conservation: a case study of Barbus barbus in Belgium. Pp. 402-413. In: Collares-Pereira M., Cowx I.G., Coelho M.M. (eds.). Conservation of freshwater fishes. Fishing News Books, Blackwell Science, Oxford, UK.

Schiemer F., Spindler T. 1989. Endangered fish species of the
Danube River in Austria. Regulated Rivers: Research and Management 4 (4): 397-407. DOI: 10.1002/rrr.3450040407

Sokal R.R., Rohlf F.J. 1969. Biometry. The principles and practice of statistics in biological research. W.H. Freeman and Co., San Francisco, USA.

Targońska K., Kucharczyk D., Żarski D., Cejko B.I., Krejszeff S., Kupren K., Król R., Dryl K., Kowalski R.K., Glogowski J. 2011. Artificial reproduction of wild and cultured barbel (Barbus barbus, Cyprinidae) under controlled conditions. Acta Veterinaria Hungarica 59 (3): 363-372. DOI: 10.1556/AVet.2011.021

Received: 24 April 2012 Accepted: 11 October 2012 Published electronically: 31 December 2012 